Konduforova Lada,

Postgraduate of the Interregional

Academy of Personnel Management,

Kyiv, Ukraine

\title{
ESSENCE OF ADMINISTRATIVE AND LEGAL MEASURES FOR THE PROTECTION OF PRIVATE INTERESTS
}

Paper analyzes the essence of administrative and legal means for the protection of private interests. It has been found out that a fundamental renovation of the national system of law brings to the agenda the issue of reviewing the understanding of the relations between public and private law. Today, theoretical sources have several approaches to understanding of these categories and how they interact, none of which has prevailed over the other. At the same time, the humanization of administrative and legal relations, based on the idea of human-centrism, necessitates the widespread use of administrative and legal means in areas that were previously considered to belong exclusively to the private-law industry. This stipulates the need for scientific search for the role and place of the identification of administrative means for the protection of private interests.

It is substantiated that administrative and legal means for the protection of private interests have a dual legal nature: they arise in the field of administrative law, but their emergence is determined by processes that are generated within other branches of law, which in the scientific literature refer to private ones (civil, labor, social, law security, etc.).

The concept of administrative and legal means for the protection of private interests has been formulated, which should be regarded as the ways and methods, by which the violated private interests of individuals and legal entities are restored, as well as the prevention of such violations in the future. The aforementioned means are implemented in administrative and legal relations, since they are related to the exercise of jurisdiction of public authorities (public administration); their use does not have the 
necessary condition for the written or verbal consent of the other party; when committing a certain violation of private interests by one party, the responsibility is exercised not by the other party, but by the public authorities of the state.

Keywords: administrative and legal measures, administrative and legal relations, administrative law, private interest, public interest, private branches of law.

\section{REFERENCES}

1. Borysevych S.O. (2011) Kryterii rozmezhuvannia publichnoho i pryvatnoho prava. "Criteria for Distinguishing between Public and Private Law". URL: http: // archive. nbuv. gov. ua / portal / soc_gum / Nrzd / 2011_2 / 1. pdf, 2011 (date of application: 11.01.2019) [in Ukrainian].

2. Maidanyk R. (2013) Pravo Ukrainy: Dualizm i Systema. Law of Ukraine: Dualism and System. Private Law 1, 26-40 [in Ukrainian].

3. Biriukova A.H. (2018) Spivvidnoshennia pryvatnoho ta publichnoho prava: dualistychnyi aspekt. "The Relation between Private and Public Law: Dualistic Aspect". Law and Society No. 4, P. 76-80 [in Ukrainian].

4. Viiskove pravo. "Military Law": a textbook / eds I. Koropatnik, I. Shopina. Kyiv: Alerta, 2019. 648 p. [in Ukrainian]. 